\begin{tabular}{lc|c|}
\hline Bentham open & The Open Biotechnology Journal \\
CrossMark & Content list available at: www.benthamopen.com/TOBIOTJ/ \\
DOI: $10.2174 / 1874070701711010081$ & $\begin{array}{c}\text { The Open } \\
\text { Biotechnology } \\
\text { lounal }\end{array}$ \\
\hline
\end{tabular}

RESEARCH ARTICLE

\title{
Mutagenic Potentials of Potable Water From Ground Sources
}

\author{
Obioma Kenechukwu Agwa*, Nkechi Joy Eze and Gideon Chijioke Okpokwasili \\ Department of Microbiology, Faculty of Science, University of Port Harcourt, P.M.B. 5323, Port Harcourt, Nigeria
}

Received: February 21, 2017

Revised: May 23, 2017

Accepted: June 08, 2017

\begin{abstract}
:
Background:

The presence of compounds with mutagenic activity in drinking water by means of short-term mutagenicity tests have been revealed in many studies. The influence of the different water treatment steps on the mutagenicity of some drinking water samples were evaluated using the Ames test.
\end{abstract}

\section{Method:}

Four different types of samples were collected from four water treatment factories within Port Harcourt metropolis: raw water from borehole (1), water after sand and granular activated carbon filtration (2), water after reverse osmosis (3), and water after Ozone and UV treatment (4). These samples were subjected to mutagenicity test using two mutant strains of Salmonella typhimurium (TA 100 and TA 98) without S9 activation enzyme.

\section{Result:}

The mutagenic analysis results revealed that raw water samples from Kent and Rivoli table water products showed mutagenic potential with TA100 and TA 98, respectively. But Kent table water showed more mutagenic potential than Rivoli and Fressi table water samples. Fressi table water is predominantly cytotoxic with all the treatment processes except for UV treatment with TA 98 strain. The finished products (water after ozone and UV treatment) of Kent table water and Rivoli table water also showed mutagenic potentials higher than those treated with TA100 and TA98 without S9 mix, respectively. Only the samples treated with activated carbon showed highly reduced mutagenic potential.

\section{Conclusion:}

This study highlights the mutagenic effects of water treatment as another quality assessment option for assessing the portability of water samples. Water treatment with activated carbon can be reintroduced after disinfection with ozone/ultraviolet to eliminate possible mutagenic by-product in the finished product.

Keywords: Drinking water samples, Finished products, Mutagenicity analysis, Quality assessment, Water treatment processes, Potable water.

\section{INTRODUCTION}

Good quality drinking water may be consumed without adverse effect on health. Such water is said to be "potable" when it is free from inorganic and organic substances, is aesthetically acceptable, free of objectionable taste, color, turbidity, and odor [1,2]. One of the major sources of potable water supply throughout Nigeria is ground water. However, many chemical contaminants have been identified in ground water mainly from industrial and agricultural practices [3 - 5]. These chemicals can have mutagenic, genotoxic and carcinogenic effects [6,7]. The potential presence of genotoxins in water results not only from anthropogenic activities such as pharmaceutical, biocidal and industrial chemical contamination, but also from other various water treatment methods [8,9]. Disinfection of drinking water to

\footnotetext{
* Address correspondence to this author at the Department of Microbiology, Faculty of Science, University of Port Harcourt, P.M.B. 5323, Port
} Harcourt, Nigeria; Tel: +2348035757992,+2348037163622; E-mails: obioma.agwa@uniport.edu.ng, o_agwa@yahoo.com 
remove and inactivate pathogens by chlorination, ozone and UV-irradiation has been shown to release by-products that can be potentially genotoxic on testing with short-term mutagenicity tests [9]. Mutagenic compounds could also be derived from corrosion or leaching from the internal surface of the water tanks and pipelines [10] which are frequently coated with coal tar or other materials such as plastics. Formation of mutagens during water distribution, as a result of chemical reaction (e.g. reaction of residual chlorine with natural organic matter during water treatment) or microbiological action, may also be possible [11]. It is therefore needful that the quality of groundwater is protected and public health not compromised by carrying out proper treatment of ground water prior to its distribution. Several reports have indicated that only a small percentage of drinking water is obtained from ground water. For example, Norway takes only 13 per cent of its drinking water from groundwater sources, whereas Austria and Denmark use groundwater resources almost exclusively for drinking water supply [12]. However, throughout Nigeria, individuals, communities, local, state and federal governments have been sinking wells and boreholes to tap the rich ground water resources for human use and irrigation purposes [13]. Serious health challenge can result from certain treatment processes carried out by drinking water factories which may be toxic and introduce mutagens. Thus, the need to evaluate the mutagenic potentials of water treatment processes of some water factories in Rivers State became necessary.

\section{MATERIALS AND METHODS}

\subsection{Research Design}

Three water factories were randomly selected for this study; Kent table water, Rivoli table water (Choba Road) and Fressi table water (Rumuokwuta), all in Rivers State). With the consent of the factory managers and quality control managers, bottle water samples were drawn.

\subsection{Samples and Sampling Technique}

Bottled water samples were collected from the above water treatment plants according to each factory's treatment processes. The steps of drinking water treatment processes took place in the following sequence: 1) sand and granular activated carbon (GAC) filtration; 2) reverse osmosis; (3) ozone disinfection; and (4) UV disinfection (finished product). The bottle water samples collected comprised raw water from borehole, water after pre-treatment i.e. sand and granular activated carbon filtration and finished product i.e. water after reverse osmosis, disinfection with ozone and ultraviolet (UV) light. Samples were serially collected in sterile $500 \mathrm{~mL}$ polyethylene terephthalate (PET) bottles after each water treatment step for mutagenic analyses. The samples were then transported to the microbiology laboratory of the University of Port Harcourt, in an iced packed cooler for immediate mutagenic analyses.

\subsection{Ames Fluctuation Test}

Ames fluctuation test was used for mutagenic analysis using the Muta- Chromo Plate Ames test kit [14]. The test strains Salmonella typhimurium (lyophilized) TA98 and TA 100 were used without S9. The test strains were rehydrated overnight prior to the assay by incubation at $37 \mathrm{C}$ for $16-24 \mathrm{~h}$ and subsequently examined for cell multiplication.

\subsection{Mutagenic Analysis}

Drinking water samples of about $100 \mathrm{~mL}$ each (raw water, water after sand and carbon filtration, water after reverse osmosis, water after ozone disinfection and water after UV disinfection) were filter-sterilized using $0.22 \mu \mathrm{m}$ sterile filter supplied with the kit in triplicates. Filter-sterilized samples of about $17.5 \mathrm{~mL}$ was aseptically dispensed into each sterile tube and labeled appropriately. The reaction mixture was aseptically prepared by measuring and mixing $43.24 \mathrm{~mL}$ from bottles $(A)+9.5 \mathrm{~mL}$ from bottles $(\mathrm{B})+4.76 \mathrm{~mL}$ from bottles $(\mathrm{C})+2.38 \mathrm{~mL}$ from bottles (D) $+0.12 \mathrm{~mL}$ from bottles $(\mathrm{E})$ into the reaction mixture container supplied with the kit. About $2.5 \mathrm{~mL}$ volume of the above reaction mixture was aseptically dispensed into each sterile tube containing $17.5 \mathrm{~mL}$ of the sample and mixed thoroughly to a final volume of $20 \mathrm{~mL}$. A blank containing $17.5 \mathrm{~mL}$ of distilled water and $2.5 \mathrm{~mL}$ of reaction mixture was prepared. Bacterial suspension from the overnight culture of about $5 \mu$ volume was pipetted into each sample tube (with the exception of the reaction blank tube) and mixed thoroughly. Negative control used was a background plate containing $17.5 \mathrm{~mL}$ of distilled water, $2.5 \mathrm{~mL}$ of reaction mixture and $5 \mu \mathrm{l}$ of bacterial culture. The positive controls for the two strains TA100 and TA98 were conducted using the standard mutagens sodium azide and 2-nitrofluorene respectively. Sodium azide of about $0.1 \mathrm{~mL}\left(\mathrm{NaN}_{3}, 0.5 \mu \mathrm{g} / 100 \mu \mathrm{l}\right)$ and 2-nitrofluorene $(2-\mathrm{NF} 30 \mu \mathrm{g} / 100 \mu \mathrm{l})$ were pipetted into sterile tube containing $17.4 \mathrm{~mL}$ of distilled water. The content of each tube (now containing test sample, reaction mixture and bacteria) was poured into the multichannel pipette reagent boat. Using the eight (8) channel multipipette, $200 \mu$ l aliquots of mixture 
was dispensed into each well of a 96-well microplate (200 $\mu$ l per well). The plates were covered with a lid, sealed in sterile airtight Ziploc bags to avoid evaporation and incubated at $37^{\circ} \mathrm{C}$ for 5 days. After the incubation period, the plates were removed from the incubator and scored for mutagenic activity.

\subsection{Analysis of Results}

The mutagenic activity of the incubated blank plates was investigated for sterility check by scoring the plates using the Muta-Chromo Plate Ames test kit instructions (EBPI Inc., Mississauga, Ontario, Canada) [14]. The blank sterility check was observed, and the assay is considered contaminated if any changes occurred in the plate. The result of each treatment plate is scored against the background mutation. The number of wells that scored positive in the treatment plate and the number of wells that scored positive in the background plates were recorded. The background plate shows the level of spontaneous or background mutation of the assay organism. When the blank plate indicates a purple it signifies that the assay was aseptically carried out; all yellow, partially yellow or turbid wells were scored as positive and all purple wells were scored as negative.

\subsection{Data Analysis}

The number of positive (yellow) wells out of 96 wells per plate was compared with the number of spontaneous revertant wells obtained with the background. The results are expressed as a mutagenicity ratio (MR): $M R=$ number of positive wells in samples/number of positive wells in the negative control [9]. Mutagenic ratio, (MR) $>2.0$ shows mutagenic risk [15 - 18]. A sample was considered mutagenic when a statistically significant increase occurred in the number of positive wells compared with spontaneous revertant wells in the background plate [9]. Statistical significance was determined using the Chi-square $\left(\mathrm{x}^{2}\right)$ analysis illustrated by [19].

\section{RESULTS}

The mutagenic potential of the water samples from three water factories in Port Harcourt were analysed using Salmonella typhimurium strains TA100 and TA 98 without S9 mix (Figs. 1-6). The results obtained from each water factory shows mutagenicity ratio (MR) of each treatment step with MR $>2$ as being mutagenic. Figs. (1) and (2) show results from Kent table water treated with strains TA 100 and TA 98, respectively. They showed various responses of the strains to the water after each stage of water treatment. MR was higher than 2 for raw water treated with TA 100 showing significant mutagenesis but lower for treatment with TA 98. The four (4) samples from Kent showed mutagenic potential with strain TA 100. Figs. (3) and (4) show results obtained from Rivoli table water. The raw water sample, water treated with ozone and water after UV light had mutagenic ratios higher than 2 upon treatment with strain TA 98. The mutagenic ratio was lower than 2 across all the samples treated with strain TA 100 indicating insignificant mutagenesis. Figs. (5) and (6) show results of samples from Fressi table water upon treatment with strains TA 100 and TA 98, respectively. These results showed predominant cytotoxicity except for the UV water sample treated with TA 98. This implies that the mutation rates observed in the cytotoxic samples were below the natural spontaneous mutation rate of the strains with slightly significant mutagenesis.

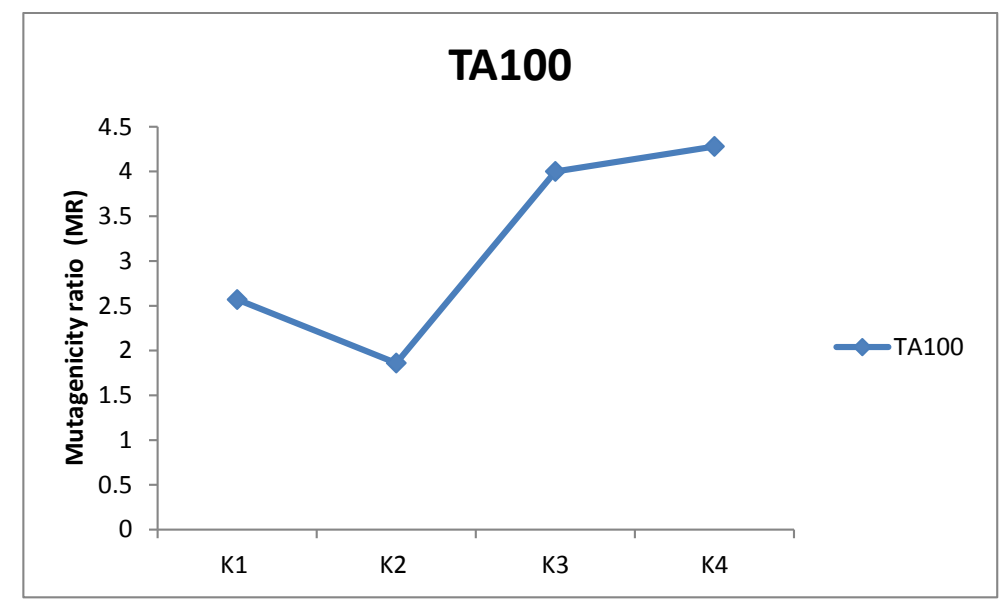

Fig. (1). Mutagenic activity of Kent water treatment steps using TA100 without S9 mix. 


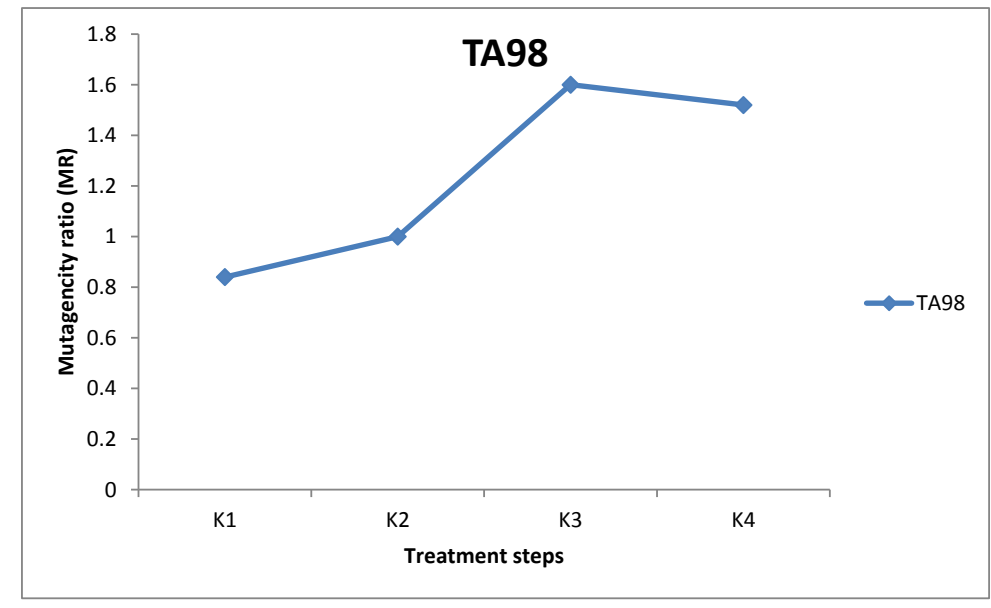

Fig. (2). Mutagenic activity of Kent water treatment steps using TA98 but without S9 mix.

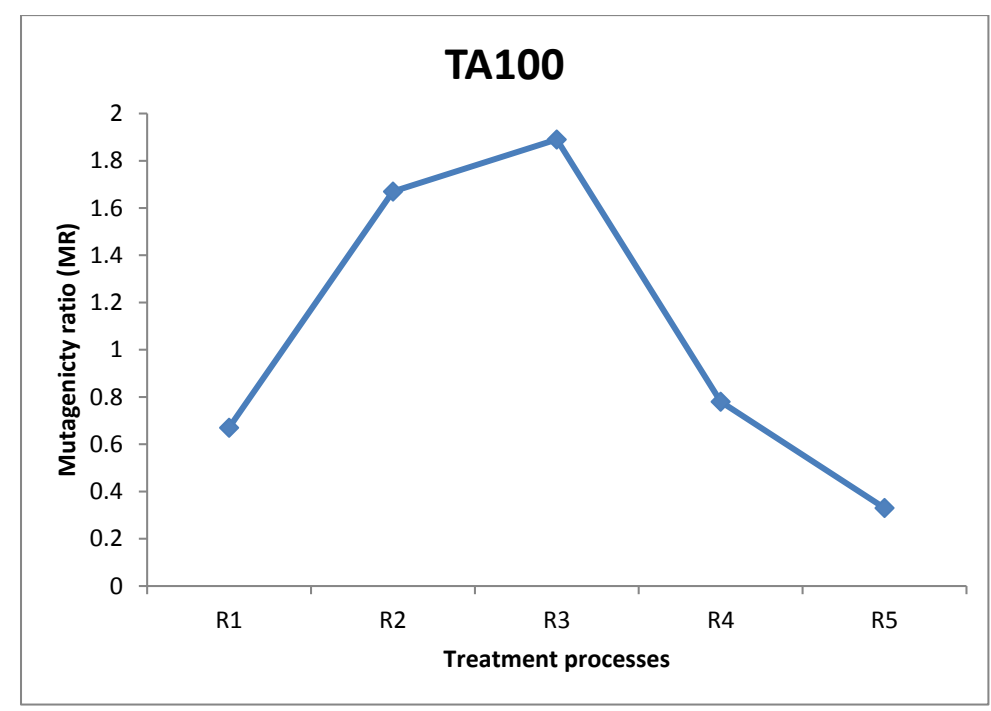

Fig. (3). Mutagenic activity of Rivoli water treatment steps with TA100 but without S9 mix.

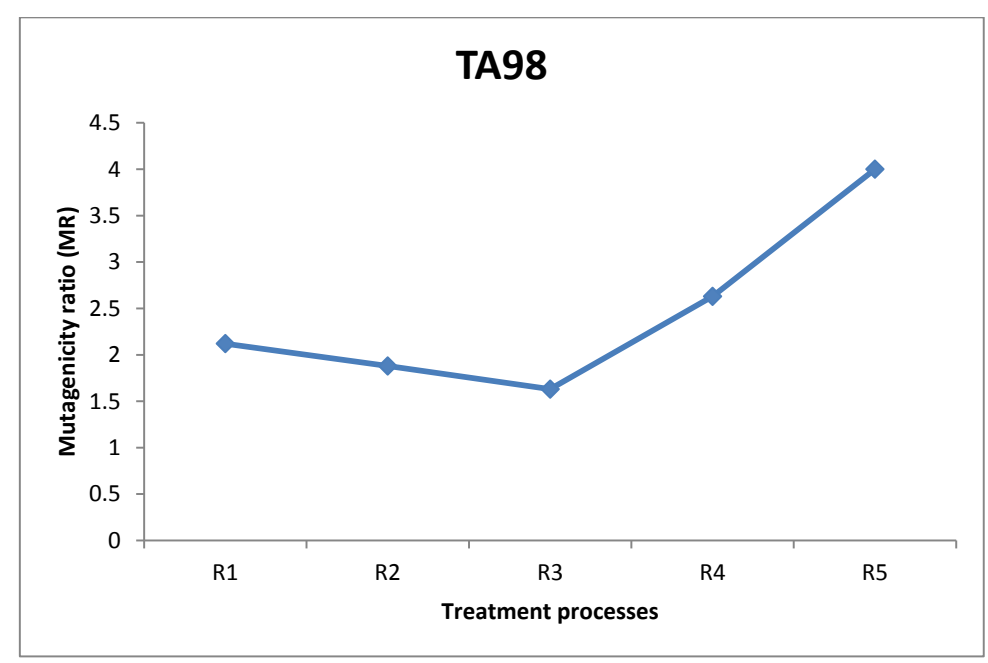

Fig. (4). Mutagenic activity of Rivoli water treatment steps with TA98 but without S9. 


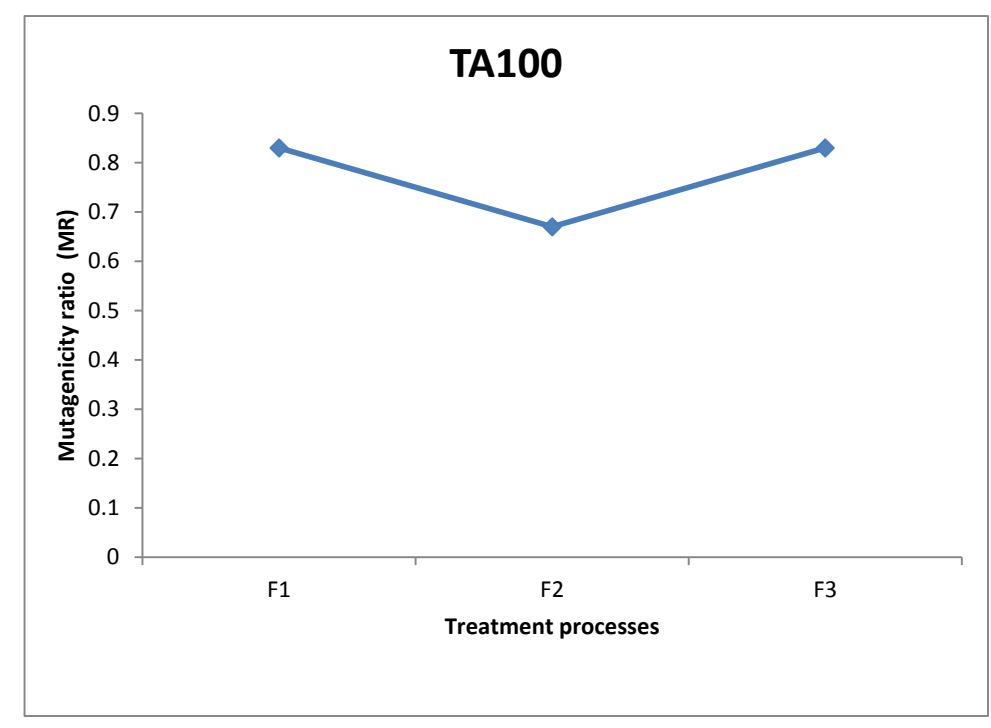

Fig. (5). Mutagenic activity of Fressi water treatment steps with TA100 but without S9.

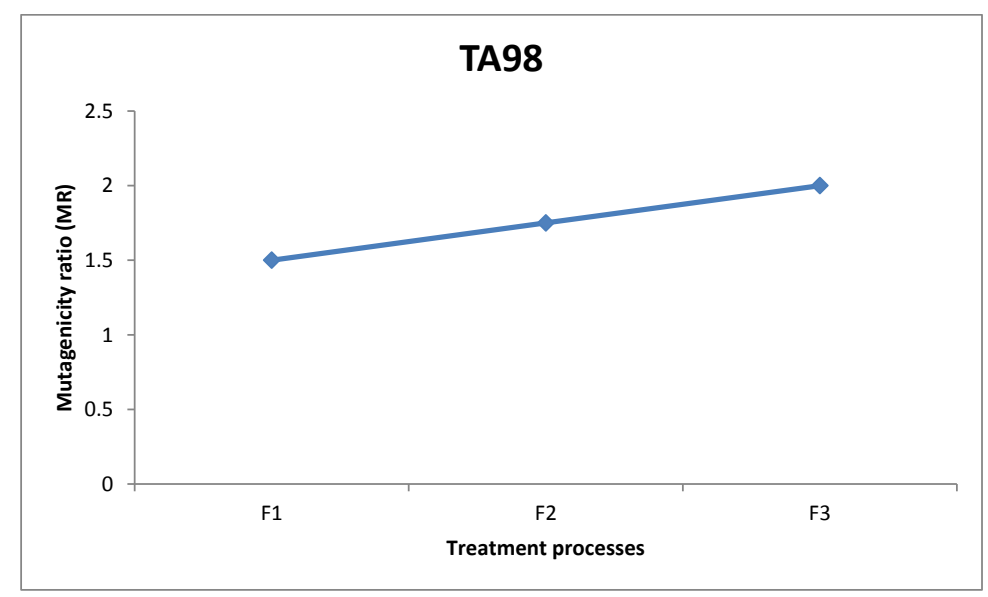

Fig. (6). Mutagenic activity of Fressi water treatment steps with TA98 but without S9.

\section{DISCUSSION}

The mutagenic activities of water samples from three bottle water factories were analyzed using Ames mutagenicity test. From the above results, raw water (K1) from Kent table water showed mutagenic potential with TA100. These unidentified substances might be natural organic substances found in the ground source. Water after sand and carbon filtration (K2) showed cytotoxic response. Water after reverse osmosis (K3) and water after ozone/Ultraviolet rays treatment (K4) showed significant mutagenicity with TA100 without S9 activation but not with TA98. For Rivoli table water, mutagenic risk was observed in raw water with TA98, water after ozone treatment (R4) and finished product treated with ultraviolet radiation (R5). The samples did not show mutagenic risk with TA100, implies that frame-shift mutagens are responsible for this mutagenic risk [20]. For Fressi table water, only the finished product treated with Ozone and Ultraviolet rays showed mutagenic risk but other samples showed cytotoxicity [21]. From this study, the finished products had mutagenic potential with Kent table water showing the greatest mutagenic risk which might be from natural products in the raw water or from run-offs such as industrial/agricultural contamination of the source water and products arising from drinking water treatment and/or distribution [22 - 24]. Disinfectants such as chlorine can introduce non-volatile mutagens in drinking water [21]. The mutagenic activity appears to originate primarily from the reactions of chlorine with the humic substances in water sources [24]. In some locations, mutagenic contaminants from 
agricultural or industrial sources contribute enormously to the mutagenicity of the finished potable water [21]. However, the factories understudied in this research did not admit to using chlorine for disinfection. Although, the trihalomethanes in chlorine-treated and non-volatile mutagens in drinking water were not determined, it is expected that the water contain some of these mutagenic substances. According to Kent table water, their raw water is treated with ozone before passage into the treatment plant. Park et al. noted that production of mutagens is greatly dependent on chlorination $\mathrm{pH}$ with a pattern of decreasing mutagenic activity with increasing $\mathrm{pH}$ [21]. The criterion for mutagenic potential used in this study revealed raw water from Kent showing the highest mutagenic risk with TA100 followed by Rivoli raw water with TA98 without S9 mix. Apart from the finished product of Fressi table water, other samples showed cytotoxicity. Similar tendencies occurred with the reports of [25 - 27]. From these conventional water-purifying processes, mutagenic activities are high in raw water, decreased through sand and carbon filtration and increased after post-treatment with ozone/Ultraviolet light. This work has not been replicated lately in Nigeria but the results are in line with already published works determining mutagenicity of other water treatment processes.

\section{CONCLUSION}

Mutagenicity tests of water treatment processes of potable water from ground sources using Ames test demonstrate that these water sources contain many unidentified and unregulated toxicants which are further changed by the treatment processes. The raw water sample and finished product (K1 and K4) of Kent water showed significant mutagenic potential with TA100 and not with TA98. This implies that Kent source water contain point mutagens. For Rivoli water, the raw water and finished products (R1 and R5) were mutagenic with TA98 and not with TA100. Water after treatment with reverse osmosis showed very slight mutagenicity. Fressi table water was mainly cytotoxic showing that the number of positive wells were mostly below the strain's natural spontaneous rate, indicating that several unidentified substances might be responsible for the cytotoxicity. Kent table water samples showed the most mutagenicity. With the exception of Kent table water, mutagenic activity was reduced after carbon filtration for both TA100 and TA98 of other table water samples analyzed.

\section{RECOMMENDATIONS}

1. Activated carbon known to remove mutagenic substances during the water treatment can be re-introduced after disinfection with ozone and UV. This will ensure that any mutagen formed from disinfection with ozone and UV will be removed before the water gets to the final consumer.

2. Regulatory bodies should enlighten bottle water factories on the continual need to give adequate treatment to the potable water from ground sources.

\section{ETHICS APPROVAL AND CONSENT TO PARTICIPATE}

Not applicable.

\section{HUMAN AND ANIMAL RIGHTS}

No Animals/Humans were used for studies that are base of this research.

\section{CONSENT FOR PUBLICATION}

Not applicable.

\section{CONFLICT OF INTEREST}

The authors declare no conflict of interest, financial or otherwise.

\section{ACKNOWLEDGEMENTS}

Declared None.

\section{REFERENCES}

[1] Haman DZ, Bottcher BD. Home water quality and safety, Circular 703, Florida Cooperative Extension Service, Institute of Food and Agricultural Sciences, University of Florida Drinking water. 1986; pp. 1-15.

[2] Gyamfi ET, Ackah M, Anim AK, et al. Chemical analysis of potable water samples from selected suburbs of Accra, Ghana. Proceedings of 
the International Academy of Ecology and Environmental Sciences 2012; 2(2): 118-27.

[3] WHO Water treatment, WHO Seminar Pack for drinking-water quality, drinking water. 1-19.

[4] Calderon RL. The epidemiology of chemical contaminants of drinking water. Food Chem Toxicol 2000; 38(Suppl. 1): S13-20. [http://dx.doi.org/10.1016/S0278-6915(99)00133-7] [PMID: 10717366]

[5] Hofer M, Shuker L. ILSI Europe Workshop on assessing health. Risks from environmental exposure to chemicals: the example of drinking water. Summary Report. Food Chem Toxicol 2000; 38(Suppl. 1): S3-S12. [http://dx.doi.org/10.1016/S0278-6915(99)00126-X] [PMID: 10717365]

[6] Monarca S, Richardson SD, Feretti D, et al. Mutagenicity and disinfection by-products in surface drinking water disinfected with peracetic acid. Environ Toxicol Chem 2002; 21(2): 309-18. [http://dx.doi.org/10.1002/etc.5620210212] [PMID: 11833799]

[7] Buschini A, Carboni P, Frigerio S, et al. Genotoxicity and cytotoxicity assessment in lake drinking water produced in a treatment plant. Mutagenesis 2004; 19(5): 341-7. [http://dx.doi.org/10.1093/mutage/geh040] [PMID: 15388805]

[8] Lah B, Zinko B, Tisler T, Marinsek-Logara R. Genotoxicity detection in drinking water by Ames Test, Zimmermann test and Comet assay. Acta Chim Slov 2005; 52: 341-8.

[9] Ubomba-Jaswa E, Fernández-Ibáñez P, McGuigan KG. A preliminary Ames fluctuation assay assessment of the genotoxicity of drinking water that has been solar disinfected in polyethylene terephthalate (PET) bottles. J Water Health 2010; 8(4): 712-9. [http://dx.doi.org/10.2166/wh.2010.136] [PMID: 20705982]

[10] Elfstrom AB, Berghult B, Hedberg T. Drinking water distribution-the effect of natural organic matter (NOM) on the corrosion of iron. Water Sci Technol 1999; 40: 17-24. [http://dx.doi.org/10.1016/S0273-1223(99)00635-6]

[11] Monarca S, Pasquini R. Mutagens in the aquatic environment. In: Cheremisinoff PN, Ed. Encyclopedia of Environmental Control Technology: Wastewater Treatment Technology, Gulf Publishing: Houston, TX, USA 1989.

[12] Schmoll O, Howard G, Chilton G, Chorus I. Protecting groundwater for health: Managing the quality of drinking-water, IWA Publishing: London, UK, 2006; pp. 23-5.

[13] Oruonye ED, Medjor WO. Physico-chemical analysis of borehole water in the three resettlement areas (Ali Sheriffti, Sagir and Dambore) in the Lake Chad Region of Nigeria. Nig J Microbiol 2009; 23(1): 1846-51.

[14] Muta-Chromo Plate, Bacterial strain Kit Version 33. Mississauga, Ontario, Canada: User's Manual. EBPI 2009.

[15] Ames BN, Mccann J, Yamasaki E. Methods for detecting carcinogens and mutagens with the Salmonella/mammalian-microsome mutagenicity test. Mutat Res 1975; 31(6): 347-64. [http://dx.doi.org/10.1016/0165-1161(75)90046-1] [PMID: 768755]

[16] Maron DM, Ames BN. Revised methods for the Salmonella mutagenicity test. Mutat Res 1983; 113(3-4): 173-215. [http://dx.doi.org/10.1016/0165-1161(83)90010-9] [PMID: 6341825]

[17] Mortelmans K, Zeiger E. The Ames Salmonella/microsome mutagenicity assay. Mutat Res 2000; 455(1-2): 29-60. [http://dx.doi.org/10.1016/S0027-5107(00)00064-6] [PMID: 11113466]

[18] Sierra CA, Müller M, Trumbore SE. Models of soil organic matter decomposition: the SoilR package, version 1.0. Geosci Model Dev 2012; 5: $1045-60$. [http://dx.doi.org/10.5194/gmd-5-1045-2012]

[19] Gilbert RI. The analysis of fluctuation tests. Mutat Res 1980; 74: 283-9. [http://dx.doi.org/10.1016/0165-1161(80)90168-5]

[20] Reifferscheid G, Oepen Bv. Genotoxicity and mutagenicity of suspended particulate matter of river water and waste water samples. Sci World J 2002; 2: 1036-9. [http://dx.doi.org/10.1100/tsw.2002.206] [PMID: 12805960]

[21] Park JH, Kang KS, Lee YS. Mutagenicity of water samples from five cities in Korea. J Vet Med Sci 2001; 63(7): 767-71. [http://dx.doi.org/10.1292/jvms.63.767] [PMID: 11503904]

[22] Filipic M. Mutagenicity and toxicity of water extracts from Sora River Mutat Res 1995; 342: 1-8.

[23] Meier JR, Lingg RD, Bull RJ. Formation of mutagens following chlorination of humic acid. A model for mutagen formation during drinking water treatment. Mutat Res 1983; 118(1-2): 25-41. [http://dx.doi.org/10.1016/0165-1218(83)90113-1] [PMID: 6223225]

[24] Meier JR. Genotoxic activity of organic chemicals in drinking water. Mutat Res 1988; 196(3): 211-45. [http://dx.doi.org/10.1016/0165-1110(88)90008-5] [PMID: 3059175]

[25] Kool HJ, Van Kreijl CF. Formation and removal of mutagenic activity during drinking water preparation. Water Res 1984; 18 : 1011-6. [http://dx.doi.org/10.1016/0043-1354(84)90252-5]

[26] Huck PM, Anders WB, Savage EA, et al. Pilot scale evaluation of ozone and other drinking water. Ozone Sci Eng 1989; 11(3): 245-69. [http://dx.doi.org/10.1080/01919518908552440] 
[27] Lee S, Lee S, Jheong W, Tae-Seung Kim T, Kim Y. Evaluation of mutagenic activity in the Nakdong river and advanced drinking water treatment processes. Mol Cell Toxicol 2010; 6: 287-93.

[http://dx.doi.org/10.1007/s13273-010-0039-9]

\section{(C) 2017 Agwa et al.}

This is an open access article distributed under the terms of the Creative Commons Attribution 4.0 International Public License (CC-BY 4.0), a copy of which is available at: (https://creativecommons.org/licenses/by/4.0/legalcode). This license permits unrestricted use, distribution, and reproduction in any medium, provided the original author and source are credited. 